Arch. hist. jap. Vol. 18, n. 4 (January 1960).

P. $473-477$.

Dept. of Anat., Yamaguchi Med. School, Ube (Director: Prof. B. OSOGOE).

\title{
Estimation of Total Number of Nucleated Cells in the Bone Marrow of Young Adult Albino Rats.*
}

若い成熟白鼠の骨髄に含まれる有核細胞総数の概算.

\section{Kazuhiko AWAYA, Hajime FUJII, Yasunori TANAKA a. Michihiko OKADA}

粟屋和彦, 藤井 肇, 田中康則, 岡田裕彦.

(Received August 28, 1959.)

In this laboratory we have been studying the quantitative aspects of the lymphocyte production in the thymolymphatic tissues of albino rats (OSOGOE et al. 1957). Along with such studies, detailed studies on the production of blood cells in the bone marrow are also being performed. In this paper we wish to present the results of some determinations on young adult albino rats conducted along this line of investigation.

\section{Material and Methods.}

Forty-one WISTAR strain albino rats weighing around $200 \mathrm{~g}$ served as the material. They were taken from the laboratory colony maintained on the standard stock diet.** In the present study it was of particular importance to employ test animals under comparable nutritional conditions and with almost identical body weights, for it is often observed that the cellular density or the rate of cell multiplication may vary, to a fairly considerable extent, depending upon the nutritional conditions and the monthly (or even weekly) age of the animal.

Immediately after stunning the animal, the bone marrow *** was taken out from the main shaft of the right femur and weighed carefully. It is transferred into a small vial containg a known volume $\left(1.0-4.0 \mathrm{~cm}^{3}\right)$ of homologous serum or human plasma and the tissues were finely dispersed in the plasma or serum by the aid of a PASTEUR pipette with a rubber bulb, to yield a homogeneous suspension of cellular material constituting the bone marrow. The volume of the serum or plasma used for diluting the cells was about 100 times the weight (or more correctly, the volume) of the bone marrow. $\dagger$ Aliquots of the bone marrow cell sus-

* Supported in part by a grant to Professor Bunsuke Osogoe from the Ministry of Education (Grant-in-Aid for Fundamental Scientific Research, Cooperative).

** The stock diet consisted mainly of unpolished rice, pressed barley and dried small sardine, added with small amounts of cod liver oil, sodium chloride and calcium carbonate.

*** About $40 \mathrm{mg}$ of the bone marrow could be obtained from one of the femora, but the main shaft of the femur yielded only $30 \mathrm{mg}$ of the bone marrow.

$\dagger$ As the medium for diluting the bone marrow, commercial human plasma yielded results not inferior to those obtained with homolgous serum. We have therefore employed mainly the human plasma in this study. 
pension so prepared were taken into 4 pipettes (checked for precision) for white blood cell counting, diluted with the TÜRK's fluid and used for estimating the number of nucleated cells per $\mathrm{cm}^{3}$ of the suspension in a NEUBAUER hemocytometer. This method was a modification of the procedure of FRUHMAN and GORDON (1953). Since the specific gravity of human bone marrow is 1.028 according to MECHANIK (1926), the number of nucleated cells contained in $1 \mathrm{~mm}^{3}$ of the fresh bone marrow (cellular density) may be obtained easily from the formula

$$
\text { Cellular density }=\frac{\begin{array}{c}
\text { Total number of nucleated cells in the specimen } \\
\text { of the bone marrow used }
\end{array}}{\text { Weight of the specimen of bone marrow used }} \times 1.028
$$

In a pilot experiment, the total unmber of nucleated cells per $\mathrm{mm}^{3}$ was compared between the right and left femoral marrows. No significant difference was noted between the two, $(1.78 \pm 0.08) \times 10^{6}$ and $(1.76 \pm 0.09) \times 10^{6}$ cells (average of 15 animals) being obtained from the bone marrows of the right and left femora, respectively. Also estimations with other 11 animals gave the following results: $(1.69 \pm 0.11) \times 10^{6}$ cells for the right femoral, $(1.70 \pm 0.07) \times 10^{6}$ cells for right tibial, and $(1.60 \pm 0.09) \times 10^{6}$ cells for the right humeral marrows and also $(1.60$ $\pm 0.06) \times 10^{6}$ cells for the left femoral, tibial and humeral marrows combined. Such results indicate that the cellular density of the bone marrows in the right and left long bones constituting the major part of the bone marrow of the whole body may be almost identical. It is for this reason that we estimated, for convenience' sake, the cellular density of the bone marrow of the right femur which served as the basis for estimating the total number of nucleated cells in the total bone marrow of the animal body.

As to the amount of the bone marrow, we used the value of $1.65 \mathrm{~g}$ per $100 \mathrm{~g}$ of body weight as given by HASHIMOTO (1953) and WATANABE (1955). The literature on the amount of the bone marrow of albino rats is scanty and only contributions by FAIRMAN and CORNER (1953) and KINDRED (1942) may be mentioned here. Values of $2.71-3.23 \mathrm{~g}$ were given by the former authors and a value of $1.18 \mathrm{~cm}^{3}$ by the latter authors as the weight or volume of the bone marrow per $100 \mathrm{~g}$ body weight. Since the fat marrow was included in the estimation of HASHIMOTO and WATANABE, their published figures may require some correction. But the relative amount of the fat marrow being unknown, their material was tentatively assumed to contain the red marrow only.

\section{Results and Discussion.}

Results of the determination performed on the right femoral marrows of 41 young adult albino rats are shown in Table 1 . The mean and the standard error of the number of nucleated cells per $\mathrm{mm}^{3}$ of fresh bone marrow is $(1.81 \pm 0.05) \times 10^{6 *}$, from which the total unmber of nucleated cells in the bone marrow of the whole

* According to MECHANIK (1926), the specific gravity of the bone marrow is 1.028 . The number of nucleated cells per $\mathrm{mg}$ of fresh bone marrow was thus calculated to be $1.76 \times$ 106. This value can be regarded as almost equal to the value of $1.81 \times 10^{6}$ cells per $\mathrm{mm}^{3}$, so that the number of cells per $\mathrm{mg}$ tissue was practically the same as that per $\mathrm{mm}^{3}$. 
body was computed to be $(5,840$ $\pm 161) \times 10^{6}$, on the assumption that the weight of the total bone marrow was 1.65 per cent of the body weight and the specific gravity of the bone marrow 1.028. The number of nucleated cells of the right femoral and total bone marrow was subject to indivdual variation, the lowest values being $1.11 \times 10^{6}$ and $3,420 \times 10^{6}$, respectively, and the highest
Table 1. Total number of nucleated cells in the whole bone marrow of young adult albino rats (average 41 rats).*

\begin{tabular}{c|c|c|c}
\hline \multirow{2}{*}{$\begin{array}{c}\text { Body } \\
\text { weight } \\
(\mathrm{g})\end{array}$} & $\begin{array}{c}\text { Marrow } \\
\text { volume } \\
\left(\mathrm{cm}^{3}\right)\end{array}$ & $\begin{array}{c}\text { Total number of nucleated } \\
\text { cells }\end{array}$ \\
\cline { 3 - 4 } & & $\begin{array}{c}\text { per } \mathrm{mm}^{3 * * *} \\
(\times 106)\end{array}$ & $\begin{array}{c}\text { per organ } \\
\left(\times 10^{6}\right)\end{array}$ \\
\hline 200.9 & 3.22 & 1.81 & 5,840 \\
\pm 1.2 & \pm 0.02 & \pm 0.05 & \pm 161
\end{tabular}

* Mean \pm standard error.

** The standard deviation was calculated to be $0.32 \times 10^{6}$ and the coefficient of variation to be $17.6 \%$.

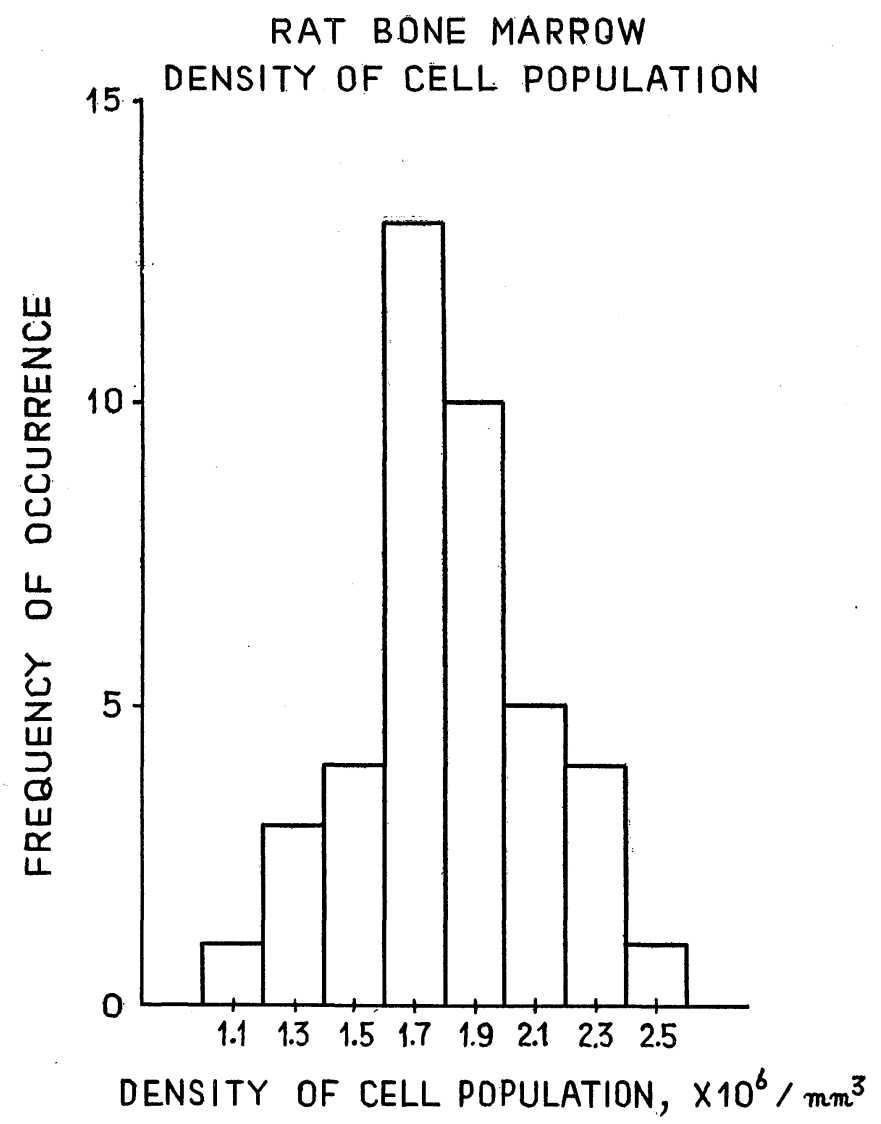

Fig. 1. Histogram of the frequency distribution of the density of cell population, expressed as the nucleated cells per $1 \mathrm{~mm}^{3}$ of fresh tissue, in the femoral bone marrow of young mature albino rats weighing around $200 \mathrm{~g}$. 
values $2.49 \times 10^{6}$ and $8,330 \times 10^{6}$, respectively. The frequency distribution of the cellular density per $\mathrm{mm}^{3}$ is illustrated in Fig. 1, its standard deviation and variation coefficient being $0.32 \times 10^{6}$ and 17.6 per cent, respectively.

Compared with the previously reported values on the bone marrow of albino rats, the above results fall about in the middle between the higher and lower values (Table 2). From the results of FRUHMAN, GORDON, MEINEKE and CRAFT it

Table 2. Number of nucleated cells per $1 \mathrm{~mm}^{3}$ of bone marrow tissue of rats estimated by different authors.

\begin{tabular}{l|c|c}
\hline \multicolumn{1}{c|}{ Author } & $\begin{array}{c}\text { Number of } \\
\text { animals }\end{array}$ & $\begin{array}{c}\text { Number of nucleated } \\
\text { cells per } 1 \mathrm{~mm}^{3} \\
(\times 106)\end{array}$ \\
\hline KINDRED (1942) & 8 & 1.98 \\
MOTA (1951) & 15 & $1.460 \pm 0.035$ \\
FRUHMAN a. GORDON (1953) & 5 & $2.40 \pm 0.11$ \\
FRUHMAN a. GORDON (1955) & 9 & $2.52 \pm 0.06$ \\
MEINEKE a. CRAFTS (1956) & 9 & $1.75 \pm 0.17$ \\
MEINEKE a.CRAFTS (1956) & 5 & $2.00 \pm 0.16$ \\
Table 1, this work & 41 & $1.81 \pm 0.05$
\end{tabular}

can be seen that the cellular density of the bone marrow varies according to the strains of the albino rat used. Thus, the cellular density of the bone marrow may be varied to an appreciable extent by the difference in the strain and diet.

Further, the differences in cellular density according to the monthly or weekly age must be considered. According to the recent study of BURKE and HARRIS (1959), the number of nucleated cells in the bone marrow of the albino rats is (2.060 $\pm 0.227) \times 10^{6}$ per $\mathrm{mm}^{3}$ on the 7 th day of postnatal growth, increases rapidly up to a value of $(3.062 \pm 0.368) \times 10^{6}$ in 6 weeks after birth, but thereafter declines sluggishly to level off at $(2.310 \pm 0.158) \times 10^{6}$ in 50 weeks. Thus, an appreciable variation in the cellular density is discernible in the bone marrow during the course of postnatal growth. Accordingly, we tried in this study to minimize such a variation by using animals of fixed body weight.

Finally mention should be made about the relationship between the amount of the bone marrow and the density of nucleated cells. It should be pointed out that only the density of nucleated cells decreases without any change in the amount of the marrow in the case of atrophy of the bone marrow. Consequently the change in the total number of nucleated cells in the bone marrow is paralleled by the change in the density of the nucleated cells it contains. In contrast to this, such is not the case in the lymphoid tissues and thymus, because both the tissue weight and the cellular density decrease in the case of atrophy of such tissues.

\section{Summary.}

Estimation of the number of nucleated cells in the bone marrows of 41 young adult albino rats weighing around $200 \mathrm{~g}$ gave a value of $(1.81 \pm 0.05) \times 10^{6}$ nucleated cells per $\mathrm{mm}^{3}$ of the fresh marrow. From this value, the total number of nucleated 
cells in the total bone marrow of the whole body was calculated to be $(5,840 \pm 161)$ $\times 10^{6}$ on the assumption that the weight of the bone marrow was 1.65 per cent of the body weight and its specific gravity 1.028 .

\section{内 容 自抄.}

体重 $200 \mathrm{~g}$ 内外の若い雄の成熟白鼠 41 匹について，骨髄におりる有核細胞数の 算定を次のごとく行った，右大腿骨骨幹部骨髄 20-30 mg をとりだして重量を正 確にはかり，乙れを 1.0-4.0立方糎の同種血清又は市販の人血プラスマをいれた ガラスの小瓶にうつし，ゴムキャップ附駒込ピペットでゆるやかに上下する。乙 のようにすると，同種血清又はプラスマ中に均等に分散した骨髄内細胞の懸濁液 が得られる，乙の懸濁液の一部を 4 本の白血球算定用ピペットにとり，Türk 液で うすめ, Neubauer 計算板で懸濁液 1 立方粍中に含まれる有核細胞数を算定した. こっでは，骨髄の此重を 1.028 (Mechanik 1926) として生鮮骨髄 1 立方粍中に含 まれる有核細胞数は

\section{$\frac{\text { サンプルとして用いた骨髓と含まれる有核細胞数 }}{\text { サンプルとして用いた骨髓の重量 }} \times 1.028$}

から求めた。 また，骨髄の総重量は体重の $1.65 \%$ という值 (橋本 1953, 渡辺 1955)

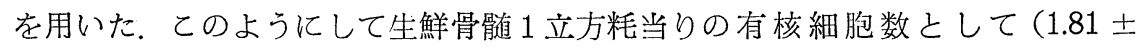
$0.05) \times 10^{6}$, 全骨髄に含まれる有核細胞数として $(5,840 \pm 161) \times 10^{6}$ という值 を得た。

\section{References.}

Burke, W. T. and C. Harris : Total cell counts of bone marrow of normal albino rats from 1 to 50 weeks of age. Blood 14 (1959). P. 409-414. - Fairman, E. and C. W. Corner : The bone marrow volume of the albino rat. Anat. Rec. 60 (1935). P. 1-4. - Fruhman, G. J. and A. S. Gordon: Quantitative evalution of total cellular numbers of bone marrow. Anat. Rec. 117 (1953). P. 603 . - Fruhman, G. J. and A. S. Gordon: A quantitative study of adrenal influences upon the cellular elements of bone marrow. Endocrinol. 57 (1955). P. 711-718. - Hashimoto, M.: Histological structure of the bone marrow. Symposium on Hematology. 5 (1953). P. 114-172. - Kindred, J. E.: A quantitative study of the hemopoietic organs of young albino rats. Amer. J. Anat. 67 (1940). P. 99-144. - Kindred, J. E.: A quantitative study of the hemopoietic organs of young adult albino rats. Amer. J. Anat. 71 (1942). P. 207-243. - Meineke, H. A. and R. C. Crafts : A study of the anemia induced by hypophysectomy and that induced by combined thyreoidectomy and adrenalectomy in Wistar, Long-Evans and Sprague-Dawley rats. Anat. Rec. 124 (1956). P. 47-66. - Mechanik, N.: Untersuchungen über das Gewicht des Knochenmarkes des Menschen. Z. Anat. 79 (1926). P. 58-99. - Mota, I. : A method for quantitative estimation of mast cells in the bone marrow of the rat. Blood 6 (1951). P. 81-83. - Osogoe, B., Y. Monden et H. Ito: Étude quantitative de la production cellulaire par le système thymo-lymphatique du rat. Sang. 28 (1957). P. 729-737. - Watanabe, S.: The weight of bone marrow. (In Jap.) J. Kyushu. Soc. Hem. 5 (1955). P. 132-157. 